\title{
SHADOW BOXING: INDONESIAN WRITERS AND THE RAMAYANA IN THE NEW ORDER'
}

\author{
Marshall Clark
}

\section{Introduction}

This article is a study of the ideas, visions, and styles of a number of Indonesia's writers in the New Order-in particular, the final years of the New Order-who chose to rework and reinterpret the Ramayana epic of the Javanese wayang kulit shadow puppet theatre. The deliberate choice by these writers to use Indonesian as their medium of linguistic communication has proven to be a decision in favor of distancing themselves from their mother-tongue, Javanese, and of targeting a larger "national" audience, thus signaling their concern for non-Javanese Indonesians. By the same token, the Indonesian language of wayang literary representations was often heavily Javanese in its flavor and style, and the indigenized wayang characters and plots appropriated were also, naturally, very much regional in origin.

Belonging to Indonesia's small yet influential political class, the target of these writers was, generally, middle-class public opinion, which they attempted to both reflect and shape. However, although the target of these writers was the Indonesian middle class, their allegiance was overwhelmingly with the non-elite and subordinate groups in Indonesian society. Yet, how can an appropriation of the wayang's feudal world of kings, queens, princes, princesses, demons, and servants possibly express an allegiance with Indonesia's "non-elite"? The answer to this question lies in the feudal kawula-gusti (servant-lord/master) ethos, one of the most basic assumptions of

1 I would like to thank Virginia Hooker, Keith Foulcher, Barbara Hatley, and Benedict Anderson, in particular, for reading earlier versions of this article, which has been significantly improved as a result of their detailed comments. 
traditional Javanese society, not to mention the heavily-Javanized New Order regime. A kawula-gusti ideology conceives society in terms of a hierarchy, in which the ruler holds sway over his kingdom unchallenged, and the achievements of his underlings are measured by their unquestioning loyalty and service to the ruler and his kingdom. ${ }^{2}$ Furthermore, the kawula-gusti ideology does not just refer to the king, but to all patronclient relations within the social hierarchy. The feudal kawula-gusti ethos was one of the first values to be questioned by many of the writers of the New Order who were reworking wayang narratives and themes. For example, in novels such as Emha Ainun Nadjib's Gerakan Punakawan atawa Arus Bawah (The Clown-servant Movement or The Undertow $)^{3}$ (1994), the menial clown-servants of the wayang hold center stage, and in their literary manifestations they constantly challenge their superiors, measuring their achievement not in terms of service to their ruler but rather in terms of their opposition to his rule and their resourcefulness in undermining it.

In Arus Bawah and other examples of Indonesian literary texts in which wayang themes were transformed-such as Agusta Wibisono's Balada Narasoma (The Ballad of Narasoma) ${ }^{4}$ (1990), Ki Guna Watoncarita's Wayang Semau Gue (Wayang as I Please) ${ }^{5}$ (1990), and Pipit Rochijat's Baratayuda di Negeri Antah Berantah (The Baratayuda in Never-Never Land) ${ }^{6}(1993)$ - the rulers themselves are often satirically caricatured as spoilt, nepotistic, corrupt, and power-hungry officials who are socially and politically ill-equipped to negotiate the ever-changing realities of life outside the palace walls. ${ }^{7}$ However, these examples are extreme, and many texts, such as Sindhunata's Anak Bajang Menggiring Angin (The Little Runt Herding the Wind) ${ }^{8}$ (1983), Putu Wijaya's Perang (War) ${ }^{9}$ (1990), and Seno Gumira Ajidarma's Wisanggeni Sang Buronan (Wisanggeni the Outlaw) ${ }^{10}$ (2000), portrayed both the wayang rulers and their subordinates in somewhat tempered shades of gray. For example, in Wisanggeni Sang Buronan, the renegade ksatria of the Pandawa, Wisanggeni, respects the opinions of authoritative ksatria (knight) figures such as his father Arjuna and the advisor to the Pandawa, Kresna. However, Wisanggeni's peasant clothes, his unkempt appearance, his taste for arak (rice wine), his allegiance to the common people, and his opposition to the wayang gods can very easily be understood as a focus of an alternative site of values and beliefs, a focus which could also be seen as a rallying point for moral resistance against the hegemonic status quo. Therefore, by treating the wayang seriously, and by broaching issues such as hierarchy and feudalism in a subtle manner,

2 For a full explanation, see Soemarsaid Moertono, State and Statecraft in Old Java: A Study of the Later Mataram Period, Sixteenth to Nineteenth Century (Ithaca: Cornell Modern Indonesia Project, 1981), pp. 1426.

${ }^{3}$ Emha Ainun Nadjib, Gerakan Punakawan atawa Arus Bawah (Yogyakarta: Yayasan Bentang Budaya, 1994).

4 Agusta Wibisono, Balada Narasoma (Jakarta: Pustakakarya Grafikatama, 1990).

5 Ki Guna Watoncarita, Wayang Semau Gue (Jakarta: Antar Kota, 1990).

6 Pipit Rochijat, Baratayuda di Negeri Antah Berantah (Jakarta: Humor, 1993).

7 For a satirical portrayal of the wayang ksatria by a non-Indonesian author, see Benedict Anderson's short story, "Mengharap Petruk Jadi Raja?," Editor 4,13 (December 8, 1990): 26-27.

8 Sindhunata, Anak Bajang Menggiring Angin (Jakarta: PT Gramedia Pustaka Utama, 1983).

${ }^{9}$ Putu Wijaya, Perang (Jakarta: Pustaka Utama Grafiti, 1990).

${ }^{10}$ Seno Gumira Ajidarma, Wisanggeni Sang Buronan (Yogyakarta: Yayasan Bentang Budaya, 2000). 
Seno's novel is as much an interrogation of the kawula-gusti ethos as the seditious satire mentioned above.

For these writers, the most obvious method of questioning the feudal Javanese ideology underpinning the New Order's cultural hegemony was to modernize and humanize the wayang characters. For example, the wayang characters translated into Indonesian literary form were often depicted as "ordinary" Indonesians who performed their tasks in a routine manner. Admittedly, their tasks may have appeared glamorous to the average Indonesian. However, the manner in which these tasks were performed was often strikingly contemporary and quite mundane. For example, rather than Gatotkaca flying off completely unaided as he does in the wayang, in one short story by Sapto Aji, Gatotkaca casually dons a jet-fighter helmet and climbs into an F16.11 Elsewhere, on the front cover of Wayang Semau Gue, an airborne Gatotkaca is pictured tangled in a kite. The front cover of Soebadio Sastrosatomo's Politik Dosomuko Rezim Orde Baru (The Politics of Dosomuko's New Order Regime) ${ }^{12}$ (1998) is distinguished by the striking image of the evil Dasamuka clutching an American dollar and a fifty-thousand rupiah note (characterized by the image of a smiling Suharto), whilst standing in a sea of five-hundred rupiah notes. ${ }^{13}$ In a story by Pipit Rochijat, Karna takes to the Kurusetra battlefield in a Toyota jeep, and he is only hit by Arjuna's arrow when his driver Salya bogs the jeep down in some mud. ${ }^{14}$ In contrast to this, Agusta Wibisono's duel between Arjuna and Karna in Balada Narasoma is highlighted by the two ksatria embracing each other, sharing a cigarette, and entering into a discussion of Karna's soon-to-be-completed novel. ${ }^{15}$ It is precisely because these usually glamorous characters are rendered so "ordinary" and "contemporary" that their message is doubly potent.

This article will argue that literary reworkings of the wayang-and, for the purposes of this article, the Ramayana epic in particular-can be read as a means of "shadow-boxing" in the face of the New Order powers-that-be. "Shadow-boxing" can be defined as boxing against an imaginary opponent. Extending this metaphor, the writers of wayang-based texts can be regarded as shadow-boxers, their texts the shadows, and their "imaginary" opponent Suharto and his New Order regime. Just as a boxer only shadow-boxes whilst warming-up or practicing before a fight, Indonesian writers critical of the New Order state were in a sense imagining, foreshadowing, and enacting in their mind's eye the "real" fight to come in 1997 and 1998, the fight to overthrow Suharto. Besides emphasizing the ways in which various Indonesian writers modernized and humanized the characters of the Ramayana, I will also try to reveal the various strategies of mediation that allowed the writers to "shadow-box" in the midst of the New Order, sometimes indirectly provoking or confronting the powers-

\footnotetext{
11 Sapto Aji, "Gatotkaca Gugur," Suara Merdeka, May 25, 1997.

12 Soebadio Sastrosatomo, Politik Dosomuko Rezim Orde Baru: Rapuh dan Sengsarakan Rakyat (Jakarta: Pusat Dokumentasi Politik "GUNTUR 49," 1998).

13 Five-hundred rupiah notes are characterized by the image of an orangutan. In the context of the front cover of Soebadio's text, the publisher claims that these notes represent "ketek-ketek yang mengabdi kepada tokoh Rama" (the monkeys who serve the hero Rama). See Soebadio, Politik Dosomuko, inside cover.

14 Pipit Rochijat, Baratayuda di Negeri Antah Berantah, pp. 38-44.

${ }^{15}$ Agusta Wibisono, Balada Narasoma, pp. 107-111.
} 
that-be, and undermining their symbolic authority, while at other times directly insulting them.

By examining various Indonesian literary texts, not necessarily in chronological order, I will try to show a lurching movement among Indonesian writers between "straight" interpretations of the Ramayana, revealing a desire for the mobilization of the Ramayana's "monkey masses," and satirical interpretations, revealing an ironic identification with the Ramayana's "evil" King of Alengka, Rahwana or Dasamuka (literally, "Ten-Faced"). By invoking mythical imagery and comic-book violence, these texts, which on the whole developed the "monkey masses" as a metaphor for the disenfranchised masses of Indonesia and Rahwana as a metaphor for Suharto, simultaneously interrogated and denounced Suharto and his New Order regime, as well as became acts of social and literary resistance.

\section{Wayang and Literature in the New Order}

Since the 1970s, more than one scholar has commented on the way in which modern Indonesian literature and drama since the late 1960s became oriented towards indigenous cultural images, forms, and values. Significantly, Keith Foulcher's 1978 study, "Image and Perspective in Recent Indonesian Literature," observes that predominantly regional orientations have emerged on several occasions in the history of modern Indonesian literature. Foulcher describes how the indigenous element was pervasive in the 1920s and 1930s, when poets and novelists incorporated indigenous elements into their literary expression "because their consciousness, as a generation, was largely informed by traditional cultural norms." 16 Traditional images and motifs re-emerged in the 1950s when the young Angkatan Terbaru (Newest Generation) writers under the leadership of Sundanese author Ajip Rosidi attempted to break with the strong European cultural orientation of the Angkatan 45 (Generation of [19]45). Foulcher observes that although Ajip Rosidi saw this group as "asserting their regional cultural roots," it is quite possible to see them "as simply writing of their own experience as part of the first generation of Indonesian-educated youth, without foreign languages, Dutch schooling, and contact with Europe which made a European cultural orientation so much a part of the experience of the Angkatan 45."17 However, in contrast to the earlier historical periods when a sense of regionalism or tradition was prevalent, the works of the late 1960s and early 1970s, and what the writers were saying about them, indicated that these writers were much more self-conscious, sophisticated, and deliberate in their choice to incorporate regional literary traditions into contemporary Indonesian art forms.

One study which highlights the deliberate nature in the 1970s of the incorporation of indigenous tradition into modern literary expression is Savitri Scherer's 1981 examination of the literary works of Yudhistira Ardi Noegraha. ${ }^{18}$ This paper is one of

\footnotetext{
${ }^{16}$ Keith Foulcher, "Image and Perspective in Recent Indonesian Literature," Review of Indonesian and Malay Affairs 12,2 (December 1978): 2.

17 Ibid., p. 2

18 Savitri Scherer, "Yudhistira Ardi Noegraha: Social Attitudes in the Works of a Popular Writer," Indonesia 31 (April 1981): 31-52.
} 
the first studies of the way in which an Indonesian writer has drawn on and poked fun at the wayang world. Scherer's study highlighted the manner in which Yudhistira manipulates the themes of the wayang to undermine the selfish interests of the New Order elite and the kawula-gusti feudal ethos. The most distinguishing aspect of Yudhistira's two novels experimenting with the wayang-Arjuna Mencari Cinta (Arjuna Searching for Love) (1977) and Arjuna Drop-Out (1980)-is the way in which Yudhistira's "wayang characters" are humorously depicted as fully humanized suburban Indonesians. ${ }^{19}$ In this sense they are no longer wayang characters as such, but rather Indonesian teenagers and adults merely named after various characters in the Mahabharata. The malicious irony in their naming lies in how the relationships between the literary characters differ from their wayang namesakes. For example, in wayang narratives, Aswatama, one of the worst of the Kurawa, completely violates ksatria ethics by treacherously murdering two women, Banowati and Srikandi, as well as attempting to kill Parikesit, who was, at the time, a mere baby in his cradle. Meanwhile, in Yudhistira's Arjuna Drop-Out, Aswatama is portrayed as an honest bank clerk who, "stupidly" refuses to indulge himself in corruption, despite being in the midst of "a corrupt environment and its corrupt society." 20

As Benedict Anderson observes in "Sembah-Sumpah: The Politics of Language and Javanese Culture," when Yudhistira steals the wayang heroes and plunges them into the "borné bourgeois world of contemporary Jakarta," he impudently unleashes his malice towards not only the ruling elite, "an establishment still sunk in the residues of colonial Javanese culture," but also the feudalism of Javanese culture itself. ${ }^{21}$ Anderson also highlights Yudhistira's usage of the Indonesian language. Anderson suggests that Yudhistira's incorporation of quotes and allusions from various languages and cultures would have been virtually impossible in Javanese, and besides, the whole point of Yudhistira's use of Indonesian for his texts was "precisely to put Java in its place."22

As a means of cultural resistance, the translation of the wayang into modern literary forms of expression continued throughout the latter half of the New Order era, if anything intensifying during the 1980s and 1990s. Why was the wayang so extensively explored and exploited for political and literary reasons in the New Order? The most obvious explanations involve politics and censorship. The first kind of explanation lies in the "dynastic" style of Suharto and his government, and in Suharto's penchant for alluding to the world of the wayang. Certainly from very early on in his political career, like his predecessor, Suharto perceived the need to link the political and the mythological. Much has been made of Suharto's early links with Semar, the popular wayang clown-god, and in his semi-official biography, there is a photo of a youthful Suharto posing in his presidential office in front of a large painting depicting Hanoman fighting Rahwana. ${ }^{23}$ However, in terms of political style, Suharto's

19 Yudhistira Ardi Noegraha, Arjuna Mencari Cinta (Jakarta: Cypress, 1977); Yudhistira Ardi Noegraha, Arjuna Drop-Out (Jakarta: Cypress, 1980).

20 "lingkungan dan masyarakatnya yang korup!" Yudhistira, Arjuna Drop-Out, p. 113.

21 Benedict R. O'G. Anderson, "Sembah-Sumpah: The Politics of Language and Javanese Culture," in Language and Power: Exploring Political Cultures in Indonesia (Ithaca: Cornell University Press, 1990), esp. pp. 227-235.

22 Ibid., p. 235.

23 See O. G. Roeder, The Smiling General (Jakarta: Gunung Agung, 1969), p. ii. 
presidency was modeled more on the values of the caste of warriors located in the upper echelons of the wayang world, the ksatria, warriors who were in turn models for the rulers of the ancient Central Javanese kingdoms. Consequently, Suharto's presidency soon took on a dynastic quality, very much in the manner of his predecessor, Sukarno. Many commentators have observed that despite the differences between Indonesia's first two presidents, the main similarity between them is an essentially hierarchical political ideology derived from the Javanese cultural tradition. Benedict Anderson's famous article, "The Idea of Power in Javanese Culture," explored the links between Sukarno and Javanese rulers, ${ }^{24}$ and Franz Magnis-Suseno and William Liddle have observed that Suharto projected an image of standing alone at the apex of government, like an idealized version of a traditional Javanese king. ${ }^{25}$ Like a king, all important political decisions, as far as outside observers such as William Liddle could detect, were made by him. ${ }^{26}$ As in the court scene of a wayang performance, Suharto received cabinet ministers and others as petitioners, rather than as colleagues. Consequently, the autocratic, "kingly" nature of Suharto's rule was a key motif of the New Order era, during which arguably the central reality of the New Order's political system of governance was "government top down," with Suharto, like a Javanese ruler of centuries past, placed firmly at the top. One could easily imagine, then, that authors critical of Suharto and his regime would focus their attention on capturing and reworking the highly stratified social structure of the wayang world for their own subversive purposes.

A second important reason for the popularity of the wayang in modern Indonesian literature is the impact of censorship. In a study on censorship in the New Order, Hendrik Maier argues, in a somewhat overly-pessimistic fashion, that for several decades Indonesia's literary life was made completely sterile. This was mainly because of the impact of censorship and self-censorship in the apolitical atmosphere of the New Order, and the subsequent trend for literature, or sastra, to move farther and farther from everyday life into a surreal "never-never land." 27 It was here, according to Maier, that writers could reflect their fragmentary personal experiences, in tales full of self-censored innuendoes and muffled allusions to the state's authority:

Suharto and his administrative apparatus have castrated a generation of writers, robbing them of their generative power, the power of being historical witnesses who could tell others about what is happening before their very eyes. Rejecting realism and strict moralism, the tales of the seventies and eighties were preoccupied with an experimental freedom and playfulness that confused the critics, alienated those who thought that "literature" still had a role to play in the New Order, and discouraged new and young readers, who subsequently turned

\footnotetext{
24 Benedict R. O'G. Anderson, "The Idea of Power in Javanese Culture," in Language and Power, pp. 17-77.

25 See Franz Magnis-Suseno, "Langsir Keprabon: New Order leadership, Javanese culture and the prospects for democracy in Indonesia," in Post-Soeharto Indonesia: Renewval or Chaos, ed. Geoff Forrester (Bathurst: Crawford House Publishing, 1999), pp. 214-228; and R. William Liddle, Leadership and Culture in Indonesian Politics (Sydney: Allen \& Unwin, 1996).

${ }^{26}$ Liddle, Leadership and Culture, p. 80.

${ }^{27}$ Hendrik M. J. Maier, "Flying a Kite: the Crimes of Pramoedya Ananta Toer," in Figures of Criminality in Indonesia, the Philippines, and Colonial Vietnam, ed. Vicente L. Rafael (Ithaca, NY: Southeast Asia Program Publications, 1999), pp. 257-258.
} 
away from sastra as a crucial manifestation of national culture. The latter effect could only please the authorities who were eager to silence discussion on the literary front [...] Censorship, invisibly and facelessly operating along various patterns of power, has done an excellent job; literary life has eliminated itself as a force for vociferous dissent, leaving only some authors and writers wandering on the savannas [. . .] where they run the risk of being made criminals. ${ }^{28}$

Admittedly, the consequences of the New Order regime's policies on freedom of expression by artists, and Indonesian society at large, were more negative than positive. Furthermore, the image of Indonesian authors and writers wandering on the savannas, an image borrowed from the man that many regard as Indonesia's greatest author, Pramoedya Ananta Toer, is apt. Nevertheless, after surveying the savannas carefully, literary life in the New Order was surely not as hopeless as Maier suggests. For example, despite Maier's low regard for writers "rejecting realism and strict moralism," surrealist writers such as Putu Wijaya, Danarto, and Seno Gumira Ajidarma, supposedly "preoccupied with an experimental freedom and playfulness," were in their own oblique way just as oppositional and political as their realist counterpart, Pramoedya. ${ }^{29}$

Importantly, those writers seeking to critique Suharto and his regime-such as the surrealist writers mentioned above and others such as Nano Riantiarno, Y. B. Mangunwijaya, and Emha Ainun Nadjib-were, at one stage or another, provoked into veiling their meanings by ingeniously developing techniques that J. M. Coetzee terms "Aesopian ruses." 30 Although the New Order's system of control and censorship was not quite as well-regulated as those found within a totalitarian regime such as the Soviet Union, writers in the New Order, especially during the latter years, worked under a shadow of fear: arrests, detentions, and bannings of books and performances were common. Attempts to outwit the authorities also became a popular occupation, and the most popular "ruse" was to turn to Java and its pre-eminent cultural expression, the wayang. This is because for centuries the dalang or wayang puppeteer has inserted contemporary references and social commentary into the wayang tales. Furthermore, the critical impact of the wayang as a literary form is even more significant because of the way wayang figured so prominently in New Order ideology as a symbol of Suharto's Java-based and Javanese-dominated governmental ties to tradition and enduring hierarchical values. ${ }^{31}$ I would argue, therefore, that one of the

\footnotetext{
28 Ibid., p. 258.

${ }^{29}$ See Paul Tickell, "Subversion or Escapism? The Fantastic in Recent Indonesian Fiction," Review of Indonesian and Malay Affairs 20,1 (1986): 50-76; Paul Tickell, "Writing the Past: The Limits of Realism in Contemporary Indonesian Revolution," in Text/Politics in Island Southeast Asia, ed. D. M. Roskies (Athens, Ohio: Center for International Studies, Ohio University, 1993), pp. 257-287; Michael H. Bodden, "Seno Gumira Ajidarma and Fictional Resistance to an Authoritarian State in 1990s Indonesia," Indonesia 68 (October 1999): 153-156; and Marshall Clark, "Seno Gumira Ajidarma: an Indonesian Imagining East Timor," Review of Indonesian and Malaysian Affairs 33,2 (Summer 1999): 33-58.

30 J. M. Coetzee, Giving Offense: Essays on Censorship (Chicago: University of Chicago Press, 1996), p. 11.

31 See Michael van Langenberg, "The New Order State: Language, Ideology, Hegemony," in State and Civil Society in Indonesia, ed. Arief Budiman (Clayton, Victoria, Australia: Centre of Southeast Asian Studies, Monash University, 1990), p. 134; Michael H. Bodden, “Teater Koma's Suksesi and Indonesia's New Order," Asian Theatre Journal 14,2 (1997): 267; and Barbara Hatley, "Constructions of 'Tradition' in New
} 
most effective ways to salvage a sense of social or political relevancy from the literary life of the New Order, and the late New Order in particular, is to focus on these writers and their "Aesopian" reworkings of the wayang world.

Some of the most memorable scholarship to examine the social and political dimensions of modern Indonesian literature during the New Order discusses writers who heavily draw upon the wayang tradition in the creation of their literary works. For example, Michael Bodden's analysis of Teater Koma's Suksesi (Succession) and Y. B. Mangunwiya's Durga Umayi, two works which appeared in 1989 and 1995 respectively, explores in detail how these texts appropriate and subvert the wayang tradition while simultaneously challenging the foundations of the New Order's authority..$^{32}$ Elsewhere, Keith Foulcher comments on the role of wayang and tradition in the fiction of leading New Order writers such as Danarto, Putu Wijaya, and Leila Chudori, suggesting that their literary expression is relevant to contemporary Indonesia and its cultural development. ${ }^{33}$ In a study written in the early 1990s, Barbara Hatley argues that from the 1970s onwards much of Indonesia's cultural expression was characterized by a vigorous reinterpretation of regional cultural traditions such as the wayang, reinterpretations which also included important critical reflections on contemporary Indonesian society. ${ }^{34}$ In a later study of modern theatre in the New Order era, Hatley goes one step further to spell out the key sociopolitical role and aesthetic characteristics of the synthesis between traditional Javanese cultural expression and modern performance art:

Absence of alternate channels of political expression arguably directed attention to performance as a site of socio-political critique. And the intimate audience connection and ideological influence of traditional, regional forms of theatre made them attractive models to follow. Theatre groups adopted the idioms of local theatre genres, but often in a satirical mode which challenged and contested their standard social meanings. Subversive renditions of traditional legends and comic caricatures of kings and courtiers undermined the discourse of contemporary power holders, seeking self-aggrandisement through association with a glorified "Javanese tradition." 35

In contrast to Maier's over-the-top pessimism, Hatley's optimistic comments could be taken as evidence that the repressive character of the New Order regime also spurred the creativity of a significant number of Indonesia's artists, at least in terms of directing their creative energy, and undeniably oppositional tendencies, to the extremely subversive potential of traditional cultural forms. In a sense, Hatley's

Order Indonesian Theatre," in Culture and Society in New Order Indonesia, ed. Virginia Matheson Hooker (Kuala Lumpur: Oxford University Press, 1995), pp. 49-50.

32 Bodden, "Teater Koma's Suksesi"; Michael H. Bodden, "Woman as Nation in Mangunwijaya's Durga Umayi," Indonesia 62 (October 1996): 53-82. Y. B. Mangunwijaya, Durga Umayi (Jakarta: Pustaka Utama Grafiti, 1991).

33 Keith Foulcher, "Postmodernism or the Question of History: Some Trends in Indonesian Fiction since $1965, "$ in Culture and Society in New Order Indonesia, pp. 27-47.

34 Barbara Hatley, "Constructions of "Tradition," pp. 48-69.

35 Barbara Hatley, "Cultural Expression and Social Transformation in Indonesia," in Reformasi: Crisis and Change in Indonesia, ed. Arief Budiman, Barbara Hatley and Damien Kingsbury (Clayton: Monash Asia Institute, 1999), pp. 268-269. 
comments underscore my rationale for studying the interaction between the wayang and modern Indonesian literature. That is, by examining "subversive renditions of traditional legends and comic caricatures of kings and courtiers," I will show that a small segment of Indonesian writers did, in fact, express vociferous dissent, and that this dissent was primarily conveyed through the subversion of "the discourse of contemporary power holders."

\section{"The Discourse of Contemporary Power-Holders": Rama Tambak}

In January 1998, at about the same time that the Asian economic crisis began seriously to undermine Indonesia's previously prosperous middle classes as well as the urban and rural poor, the Indonesian government sought a "spiritual solution" to the crisis. The Minister for Tourism, Post and Telecommunication, Joop Ave, suggested the performance of a particular wayang tale, Rama Tambak. Located in the Ramayana cycle of tales, Rama Tambak recounts Rama's attempt to rescue his kidnapped wife, Sinta, from the clutches of the evil King of Alengka, Rahwana (also known as Dasamuka). Alengka is an island kingdom: to rescue his wife Rama must transport his army of monkeys, which is under the leadership of Hanoman and Sugriwa, across the sea. Being an incarnation of the god Wisnu, Rama decides to shoot his powerful arrow, the Gunawijaya, into the waves. This arrow will dry out the water and allow his army to cross over on foot. But just in time, the Sea God Baruna manages to convince Rama not to do so since the "environmental impact" would be catastrophic. ${ }^{36}$ Thus, Rama decides instead to build a colossal tambak, or causeway, linking the two land-masses. Eventually with the help, cooperation, and sacrifice of thousands of monkeys, the causeway is successfully completed, despite constant attacks by Alengka's hordes of crocodiles, crabs, and ogres. As soon as Alengka is in sight, a command post is constructed and the final assault is launched.

In the hope that Rama Tambak would have a positive impact upon the economic crisis, Joop Ave allocated 150 million rupiah for the project. ${ }^{37}$ Considering the billions of dollars committed to the Indonesian economy through the IMF, 38 without producing any tangible signs of success, a mere 150 million rupiah for a "spiritual solution" to Indonesia's grave economic condition, with no strings attached, may have seemed a bargain, at least from the perspective of the Indonesian government. The first performance was held in Jakarta on February 13, 1998, led by Ki Manteb Sudharsono, long considered the leading dalang of Surakarta. Shown live on the state television station, TVRI, and broadcast live on the state radio station, RRI, Ki Manteb's performance was enhanced by over eighty gamelan musicians and singers, a screen

36 According to one of the leading dalang of Yogyakarta, Ki Timbul Hadiprayitno, Baruna tells Rama that even if he succeeded in removing the water, his troops would find it quite slow and difficult crossing the ocean floor, as it is covered with mountains. See Bersihar Lubis, Kastoyo Ramelan and Joko Syahban,

"Rebut Sinta, Pulihkan Rupiah," Gatra, February 7, 1998, p. 106.

37 See "'Rama Tambak' dalam Gejolak Moneter," Suara Merdeka, February 5, 1998.

38 In early November 1997 the IMF approved roughly US\$10 billion in financial support. See Mark McGillivray and Oliver Morrisey, "Economic and financial meltdown in Indonesia: prospects for sustained and equitable economic and social recovery," in Reformasi: Crisis and Change in Indonesia, pp. 19-20. 
seventeen meters wide, the use of dry ice, and special sound and light effects. ${ }^{39}$ Over the next week performances were also given in Bandung, Surabaya, Semarang, Yogyakarta, and Solo. Apart from Ki Manteb, the shadow puppeteers involved included another highly respected Solo-based dalang, Ki Anom Suroto, the senior Yogyakarta-based dalang, Ki Timbul Hadiprayitno, the leading Bandung-based wayang golèk puppeteer, Asep Sunandar Sunarya, the popular Tegal-based dalang, Ki Enthus Susmono, and the lesser known Ki Suryanto Purbocarito and Ki Wisnu Warsito.

Solichin, the chairman of the pro-government wayang shadow puppeteering organization Senawangi, observed that the timing of the project was very important, because the crisis facing the Indonesian nation strongly resembled the crisis confronting Rama, whose kidnapped wife Sinta could easily be seen as a representation of the goddess Dewi Pertiwi, the symbolic embodiment of Indonesia herself. ${ }^{40}$ Meanwhile Wirabumi, the son-in-law of the Susuhunan of Surakarta, Paku Buwono XII, likened the kidnapped Sinta to the rupiah's dollar exchange-rate, which desperately needed rescuing. ${ }^{41}$ Joop Ave preferred to view the kidnapped Sinta not so much as the exchange rate in particular, but rather the Indonesian economy as a whole. ${ }^{42}$ Furthermore, a month before the performances, Joop Ave observed publicly that Rama Tambak was the very same lakon (wayang tale) performed for President Suharto whenever he faced serious problems in the early years of his presidency. ${ }^{43}$ Perhaps the embattled Suharto felt that it was time to revive his earlier association with Hanoman, who, despite the fact that he is a mere monkey, is also the key to Rama's eventual success.

In addition, on January 17, 1998, the same day that Joop Ave invited Indonesia's leading dalang to perform Rama Tambak, Paku Buwono XII was reported to have received a wisik (a message from a god or some other supernatural power) during the first ruwatan (ritual purification ceremony) held in the Surakarta palace in 253 years. The wisik suggested that for the sake of the nation Rama Tambak be performed. ${ }^{44}$ According to the Susuhunan, the Rama Tambak tale enacts the important philosophical idea of Manunggaling Kawula lan Gusti, or unity between the common people and the state. Hence, by watching and listening to Rama Tambak, the Indonesian kawula or rakyat (common people) would see that the only way out of the economic crisis was to unite behind the same philosophy and work with one another and with their gusti, the New Order government. The next section, after very briefly examining the immediate critical and artistic responses to the Rama Tambak phenomenon, will focus on the ways in which literary appropriations of the characters and tales of the Ramayana radically diverged from this pro-government Manunggaling Kawula lan Gusti interpretation.

\footnotetext{
39 See "Rama Tambak Digelar Penuh Gebyar," Suara Merdeka, February 14, 1998; "Membendung Krisis ala Sri Rama," Forum Keadilan 6,24 (March 9, 1998): 65.

40 "Membendung Krisis ala Sri Rama."

41 "Pentaskan Wayang Kulit 'Rama Tambak," Kompas, January 19, 1998.

42 "'Rama Tambak' dan Krisis Ekonomi," Kedaulatan Rakyat, January 8, 1998.

43 "Rebut Sinta, Pulihkan Rupiah."

44 "Pentaskan Wayang Kulit 'Rama Tambak.,"
} 


\section{Rama Tambak vs. Politik Dosomuko Rezim Orde Baru}

In the days and weeks following the Rama Tambak performances the reaction from cultural critics and journalists was cool, to say the least. ${ }^{45}$ The shows appeared to be dynamic and innovative in their presentation, yet ultimately they lacked the gravity that the occasion, and the preceding media hype, demanded. True enough, it was widely reported that $\mathrm{Ki} \mathrm{Manteb}$ had actually fasted for two days and two nights prior to the show, and practiced with his musicians intensively for a week, treating his Rama Tambak performance more seriously than any other he had ever performed. Afterwards, he had even claimed it as the pinnacle of his illustrious career. It was also well-publicized that $\mathrm{Ki}$ Manteb had intended to imbue his performance with an "authoritative" element, and the huge screen and light and sound effects were seen as an integral part of this strategy. However, the glitz and glamour dominated to such an extent that it overshadowed any "authoritative" essence. Furthermore, by focusing on the political intrigues of the ksatria, the important role of the monkeys was overlooked. A magazine review describes Manteb's performance in the following way:

It's a pity that in Manteb's performance the very authority that he had hoped for was precisely overwhelmed by the flashiness on show. Also missing was a focus on the role of the rakyat. The problem was, what dominated was the intrigue between court officials who wanted to render their services. This was as much to do with monkey commanders such as Anila and Anggada, as with Sugriwa's suspicion towards Gunawan Wibisana, Rahwana's brother, who deserted and joined Sri Rama's side. Meanwhile the rakyat, even though their sacrifice was the greatest, as usual, as in other wayang tales, they were not put center-stage. Perhaps, this doesn't need to be worried about too much. After all, that's exactly what happens to the rakyat outside the wayang. ${ }^{46}$

Also in 1998, in stark contrast to the dalang involved in the Rama Tambak phenomenon, Indonesian writers and political activists were making no secret of the fact that they saw the monkeys as a metaphor for the Indonesian masses and Rahwana as a perfect metaphor for Suharto. As a reflection of this, consider the following pantun poem, ${ }^{47}$ which was entered into a "Plesetan Pantun" (Play on Pantun) competition in a Yogyakarta newspaper soon after Suharto resigned as president:

\footnotetext{
45 See "Rama Tambak Digelar Penuh Gebyar"; "Ruwatan 'Rama Tambak' Dianggap Tidak Lebih dari Hiburan," Suara Merdeka, February 16, 1998; "Penonton tak Terusir di 'Rama Tambak," Kompas, February 16, 1998; "'Rama Tambak' di Sala Gagal 'Nambak Guyonan,'" Suara Merdeka, February 24, 1998; "Membendung Krisis ala Sri Rama."

46 "Sayangnya, dalam pergelaran Manteb, kewingitan yang diharapkannya justru tertindih oleh kemegahan yang tampil. Yang juga luput adalah sorotan terhadap peran rakyat. Soalnya, yang banyak muncul justru adalah intrik di antara punggawa yang ingin berbuat jasa. Baik sesama pasukan kera seperti antara Anila dan Anggada, maupun kecurigaan Sugriwa terhadap Gunawan Wibisana, adik Rahwana, yang membelot ke kubu Sri Rama. Sementara rakyat, kendati paling berat pengorbanannya, apa boleh buat, seperti halnya dalam cerita wayang lainnya, tidak mendapat tempat utama. Barangkali, itu memang tak perlu terlalu dirisaukan. Soalnya, itulah pula yang lazim terjadi pada rakyat di luar panggung wayang." "Membendung Krisis ala Sri Rama," p. 65

47 A pantun is a form of traditional Malay poetry in which each quatrain consists of two rhymed couplets. The first couplet is linked with the second couplet both through its sound and through allusion, although the point of the allusion is often difficult to grasp.
} 
A young couple were riding on their bikes

Roaming very very far

After three decades and two years

That was the end of the story about that guy Dasamuka. ${ }^{48}$

Cheerfully referring to the end of Suharto's thirty-two years as president of Indonesia, this poem is testament enough to the widespread conceptualization, and representation, of Suharto as a latter-day Rahwana/Dasamuka. T-shirts designed and printed in Solo early in $1998,{ }^{49}$ depicting a caricature of Rahwana strongly resembling Suharto as the gaoler of the many missing student activists at the time, also reinforced the image of the President as an "evil kidnapper," intent on thwarting the student-led reformasi movement.

A similar theme was developed at the same time by Soebadio Sastrosatomo, the aged Sukarno-era socialist leader and author of Politik Dosomuko Rezim Orde Baru (1998). Soebadio's book, which is based on a humorless reading of the Ramayana's oppositional conflict between Dasamuka and the monkey army, undeniably represents Suharto as Dasamuka and the monkeys as ordinary Indonesians. Throughout the twenty-three pages of Politik Dosomuko, Soebadio is scathing in his attack on Suharto's "evil" rule, claiming that throughout Suharto's presidency the Indonesian people were harshly oppressed. The dominant motif of Soebadio's highly polemical text is based upon the conceit that Suharto began and continued his rule of Indonesia in the same manner as Dasamuka had done in Alengka. Under the heading "Dosomuko's Political System," Soebadio bitterly claims that Dasamuka's ten faces represent ten aspects of Suharto's regime: the eradication of the rakyat's sovereignty; the manipulation of the Pancasila as a means of political control; the neutralization of the legal system; the repression of political parties and workers' unions; the emasculation of the parliament; the censorship of the mass media; the development of an economy rife with nepotism, corruption, and collusion; the de-intellectualization of the education system; the standardization of culture; and the violation of basic human rights. ${ }^{50}$

Marc Perlman has observed that Soebadio's "blistering" comparison between Dasamuka and Suharto's regime would do many a dalang proud. ${ }^{51}$ Significantly, Politik Dosomuko appeared in February 1998, and was banned and withdrawn from sale on April 22 of the same year, in the month before Suharto's resignation. ${ }^{52}$ This shows how seriously, and personally, such writing was taken by the President, confirming the remarks of a nineteenth-century editor of Aesop: "A tyrant cannot take notice of a

48 Dua sejoli bersepeda

Jauh di sana berkelana

Usia tridasa dwiwarsa

Tamat lakon si-Dasamuka. S. Maharani, Minggu Pagi 51,8 (July 1998).

${ }^{49} \mathrm{My}$ thanks to Helen Pausacker, who was living in Solo at the time, for showing me one of these T-shirts.

50 Soebadio Sastrosatomo, Politik Dosomuko Rezim Orde Baru, pp. 3-4.

${ }^{51}$ Marc Perlman, "The Traditional Javanese Performing Arts in the Twilight of the New Order: Two Letters from Solo," Indonesia 68 (October 1999): 25.

52 See "Buku 'Politik Dosomuko' Karya Soebadio Dilarang," Kompas, May 8, 1998; and "Soebadio Sastrosatomo Tutup Usia," Kompas, December 8, 1998. 
Fable without putting on the cap that fits." 53 Suharto had every reason to be concerned. The timely appearance of Soebadio's text indicated that in the hearts and minds of ordinary Indonesians in early 1998, the characters and stories of the Ramayana had much more in common with the subversive sentiments of the reformasi movement than the hollow Manunggaling Kawula lan Gusti exhortations of the statesponsored Rama Tambak performances. As will become evident when we examine a number of the literary interpretations of the Ramayana cycle in more detail, the social embeddedness of the texts stretches well beyond obvious associations between Rahwana and Suharto. Imaginative appropriations of other Ramayana characters such as Wibisana, Sinta, and Hanoman also mediate between the world of myth and contemporary Indonesia. Furthermore, we will also find that socially and politically engaged literary interpretations of the Ramayana cycle appeared in Indonesia long before early 1998. For example, Sindhunata's Ramayana-based novel, Anak Bajang Menggiring Angin, was first published in 1983. Beginning with a discussion of Sindhunata's novel, the remainder of this article will focus on the innovative forms that various reworkings of the Ramayana have taken, the subversive values they embody, and the many intriguing ways in which they contested the symbolic authority of Suharto and his New Order regime.

\section{Sindhunata's Anak Bajang Menggiring Angin: Liberating the "Ugly Ones"}

Sindhunata was born in Malang, East Java, on May 12, 1952. An ordained Catholic priest who is also a writer, essayist, and journalist, he is best known for his cultural columns and soccer commentaries. In 1992 Sindhunata graduated in Germany with a PhD in philosophy, and he currently works in Yogyakarta as editor of a Catholic cultural studies magazine, Basis. Sindhunata's first novel, the highly poetic Anak Bajang Menggiring Angin (The Little Runt Herding the Wind) (1983), is closely based on the Ramayana cycle of tales. ${ }^{54}$ However, thematically Anak Bajang is quite innovative, reflecting an understated commitment to social and political reform. The key innovation in Sindhunata's novel is the emphasis placed on representing the marginal figures in the stories of the Ramayana cycle: the monkeys, the demons, and the ogres. ${ }^{55}$ In the wayang today, the monkeys are usually regarded as symbolic representations of the Indonesian rakyat. This symbolism is embraced in Anak Bajang, with the addition of ogres and demons, who are also treated as representations of the rakyat. Considering that in the early 1980s the New Order's heavily Javanised cultural hegemony was at the height of its strength, shifting the wayang's ksatria-oriented focus

53 Joseph Jacobs, quoted in Annabel Patterson, Fables of Power (Durham: Duke University Press, 1991), p. 17.

54 Sindhunata, Anak Bajang Menggiring Angin.

55 In terms of theatre, the monkeys are not marginal at all in the Ramayana cycle. Some dalang deliberately choose to perform stories from the Ramayana, or at the very least incorporate a Ramayana character such as the monkey Hanoman into non-Ramayana performances, so that they can show off their ability to perform the spectacular fighting movements of the monkeys. As a consequence, stories from the Ramayana are often referred to as 'lakon kethek' (monkey tales). See Jan Mrázek, "Phenomenology of a Puppet Theatre: Contemplations on the Performance Technique of Contemporary Javanese Wayang Kulit" (PhD dissertation, Cornell University, 1998), pp. 102-103. 
into a rakyat-oriented framing is a significant philosophical transformation, which carries important social and political resonances.

Another distinctive feature of Sindhunata's novel is its highly lyrical prose style. It could be argued that the lyrical language and style of Anak Bajang harks back to the world of Javanese tradition, a common literary motif of the 1980s, when several major texts conveyed regional traditions in a nostalgic fashion. ${ }^{\mathbf{5 6}} \mathrm{It}$ could also be argued that Sindhunata was under the stylistic influence of another Yogyakarta-based Catholic priest and writer of a number of novels in the 1980s and 1990s, Y. B. Mangunwijaya, who also often wrote in a highly lyrical manner. Nevertheless, Sindhunata says that the "highly poetic" style of Anak Bajang is not so much based on the style of any other Indonesian writer, or the wayang for that matter. Instead, it is based on the lyricized "folk" style popularized by one of Spain's leading socialist writers of the twentieth century, Federico Garcia Lorca. ${ }^{57}$ Just as Lorca rewrote folk tales in lyrical prose as a means of strengthening the political consciousness of his fellow countrymen, in Anak Bajang Sindhunata uses a similar style to revitalize and transform what he felt was the "narrow" confines of wayang, in order to inspire the people of Indonesia to take their sociopolitical fate into their own hands.

Unlike a standard wayang performance, which usually begins in the first scene with a lengthy description of the palace and the state of the kingdom, Sindhunata's novel begins with a poem introducing some of the devils and demons that so heavily populate his version of the Ramayana. After a lengthy foray into the calamitous events surrounding the birth of the evil Rahwana and his siblings, Kumbakarna and Sarpakanaka, minimal attention is given to Rama and Sinta, who are usually the central figures of the Ramayana. In the author's words,

I abandoned the old way which usually highlighted the beauty of the ksatria and human beings. The main characters of Anak Bajang were not ksatria such as Rama or Sinta, but rather those who have been categorized as the ugly ones, such as the monkeys, the ogres and the formless creatures inhabiting the world of spirits. ${ }^{58}$

This focus was quite deliberate, and highlighted Sindhunata's desire to promote his vision of both the need for and the means by which social and political transformation could take place in Indonesia. According to Sindhunata, the wayang has traditionally represented virtue as sharply contrasted with evil, and the former always defeats the latter in the end. ${ }^{59}$ However, Sindhunata argues that such a rigid polarity leaves little room to explore the more ambiguous "gray" areas of reality, not to mention the everyday struggles of human nature, where one must overcome one's inherent sinfulness in order to allow goodness and virtue to prevail. By juxtaposing the marginal beings of the wayang world with the ksatria in Anak Bajang, Sindhunata

\footnotetext{
56 Barbara Hatley, "Cultural Expression," in Indonesia"s New Order: the Dynamics of Socio-economic Transformation, ed. Hal Hill (St. Leonards, Sydney: Allen \& Unwin, 1994), pp. 216-266.

57 Sindhunata, "Semar dan Estetika Kejelekan," in Bayang-Bayang Ratu Adil (Jakarta: PT Gramedia Pustaka Utama, 1999), pp. 211-228.

58 "Saya meninggalkan cara lama yang biasanya mengagungkan keindahan para ksatria dan manusia. Pelaku utama Anak Bajang bukanlah para ksatria seperti Rama dan Sinta, melainkan mereka-mereka yang tergolong jelek, seperti kera, raksasa dan makhluk-makhluk tak berbentuk di alam alus." Ibid., p. 218.

59 Ibid., p. 222.
} 
addresses more fully these ambiguities of human nature. This thematic focus is part of what Sindhunata terms an "aesthetics of ugliness," a literary strategy inspired by the nineteenth-century German philosopher Karl Rosenkranz. ${ }^{60}$ An aesthetics of ugliness rests on the hermeneutic notion that if cultural expression intends to depict the interconnected totality of human existence, then it must show, for example, that beauty co-exists with ugliness, or that sickness is in a constant dialectic with health, and vice versa.

The key to understanding the sociopolitical significance of the marginal beings in Anak Bajang lies in grasping the symbolism of their "ugliness." Three human siblingsGuwarsa, Guwarsi, and Dewi Anjani-are personally confronted by this "ugliness" when they are transformed into monkeys. ${ }^{61}$ These children are distraught at this turn of events, and when their father, Resi Gotama, discovers them, he is overcome with grief. However, Resi Gotama soon checks himself and realizes the positive aspect of his children's transformation. Their suffering, he claims, will become a crucial factor in fighting the evil Rahwana:

"Guwarsa, Guwarsi, and Anjani, my children. Don't be sad. For the world now greatly yearns for your suffering at the moment. You have become monkeys, abject creatures. But precisely by being monkeys you will be aware of your true natures as titah [creatures], who are nothing in the face of their Creator."

"Over there across the sea, wickedness and pride are enthroned in an earthly creature, who desires to reach above his station as a titah ... His wickedness and pride can only be quelled by those who are aware of themselves as titah, as small, and as insignificant. This pride can only be quelled by humility, my children. Be happy you three, because it is precisely by being in the form of monkeys that you will easily be aware of yourselves as titah."62

Although both Rahwana and the monkeys are described as titah (an Old Javanese word taken up by Javanese Catholicism to mean one of God's creatures or creations), there is a vast difference in outlook between them. Unlike Rahwana, who thinks he is some kind of god, the monkeys are very much aware that they are not "complete" as human beings: "monkeys are titah longing for the completeness of human beings." 63 By

60 Ibid., p. 217.

${ }^{61}$ Guwarsa and Guwarsi become monkeys after they dive into a lake in search of the Cupu Manik Astagina, a magical pillbox containing visions of the past and the future. The box was their sister Dewi Anjani's keepsake, a gift from her mother, Dewi Windradi, which was in turn a gift from her lover, the sungod Batara Surya. After Dewi Windradi's husband, Resi Gotama, discovered his wife's infidelity, he threw the pillbox into a lake. Soon after Guwarsa and Guwarsi attempted to retrieve the box, Dewi Anjani herself dives into the lake, and also resurfaces covered in monkey fur.

62 "Guwarsa, Guwarsi, dan Anjani, anakku. Janganlah kau bersedih. Sebab penderitaanmu saat ini sangat diinginkan dunia. Kau telah menjadi kera, makhluk yang hina. Tapi justru sebagai kera itulah kau akan menyadari hakekat dirimu sebagai titah, yang tiada artinya apa-apa di hadapan Penciptanya."

"Di seberang sana, telah bertahta kejahatan dan kesombongan dalam diri seorang makhluk dunia, yang ingin melebihkan dirinya sebagai seorang titah. Kesombongannya dan kejahatannya tidak dapat ditaklukkan oleh siapa pun juga, kecuali oleh mereka yang menyadari diri sebagai titah, yang kecil, dan tak berarti apa-apa. Kesombongan itu hanya bisa ditaklukkan dengan kerendahan hati, Anakku.

Berbahagialah kamu bertiga, karena kamu akan dengan mudah menyadari dirimu sebagai titah, justru dalam rupa kera." Sindhunata, Anak Bajang Menggiring Angin, pp. 42-43.

63 "kera adalah titah yang merindukan kesempurnaan manusia." Ibid., p. 43. 
accepting their incompleteness, the monkeys are thus more inclined towards enduring suffering with humility, forbearance, and hope, ultimately ensuring that "from that very suffering the world will obtain its happiness." 64 The chastened Guwarsa and Guwarsi, whose names are changed to Sugriwa and Subali, thus go off to meditate. For their efforts, they are rewarded by the gods with supernatural powers. For example, Subali is given the sacred mantra, Pancasona, which guaranteed him invincibility in battle as long as his body never lost contact with the ground. Later, Subali and Sugriwa bitterly oppose each other, yet their feud seals the alliance between Sugriwa and Rama for the invasion of Alengka to rescue Rama's abducted wife.

After being transformed into a monkey Dewi Anjani also chooses to meditate, and her humility and suffering is rewarded by the gods with her conception and birth of Hanoman, "who is greatly awaited". ${ }^{5}$ Of course, Hanoman was also instrumental in the defeat of Rahwana. Reflecting Sindhunata's Catholic faith, Dewi Anjani's Marylike qualities of suffering, servitude, and humility-which are also embodied in her son, the messianic Hanoman-are emphasized as the means to overcoming the evil of Rahwana. The Christ-like sentiments associated with the monkeys, and Hanoman in particular, is an important link between Anak Bajang and Sindhunata's later wayangbased novel, Semar Mencari Raga (Semar Looking for a Body) (1996), in which Semar is portrayed as a debased yet redemptive leader of the masses against an oppressive power. ${ }^{66}$

Although the monkeys of Anak Bajang are not explicitly linked with the rakyat of Indonesia, in a large number of Sindhunata's essays, the rakyat is presented as the saving grace of the Indonesian state. For example, in one essay, "Petruk Dadi Ratu" (Petruk Becomes King), ${ }^{67}$ based on the famous lakon in which Petruk becomes king after Abimanyu, his master, falls ill, the clown-servant Petruk describes the crucial role of the rakyat in the kingdom's governance. Reminiscing in his old age, Petruk describes how when he became king he named himself Lord Wel-Geduwel-Beh, legalized opium smoking, and promoted gambling until it was the kingdom's number one sport. However, despite possessing the necessary three holy wahyu (divine rights to rule), he was unable to sit firmly on Palasara, the throne of Astina, as he kept falling off. The only way he could remain on the throne was by letting Abimanyu sit on his lap. At that point Petruk realized his true calling was as a member of the rakyat, best suited to supporting the king on his throne, "menyempurnakan hidup raja" (to perfect the life of the king) ${ }^{68}$ By the same token, Petruk warned that a king cannot rule properly without the help of the rakyat holding him up. If a king were to rule without respecting the rights of the rakyat, he would soon lose his wahyu. The king's complete dependence on the rakyat was emphasized when Petruk recounted that when Abimanyu died on the battlefield of the Baratayuda his body was picked up and buried by Petruk himself. In short, according to Petruk, "the king and the rakyat must look after each-other,

\footnotetext{
64 "dari penderitaan itulah dunia akan memperoleh kebahagiaannya." Ibid.

65 "sangat dinanti-nantikan..." Ibid., p. 47.

66 Sindhunata, Semar Mencari Raga (Yogyakarta: Kanisius, 1996).

67 Sindhunata, "Petruk Dadi Ratu," in Bayang-Bayang Ratu Adil, pp. 146-150.

68 lbid., p. 149.
} 
embrace each-other, support each-other, like a lion and the jungle, like Abimanyu and Petruk."69

In the pages of Anak Bajang it is quite clear that like Abimanyu, Rama is very much dependent on the help of the rakyat. This dependence is reflected in a physical sense by Rama's reliance on Hanoman to locate Sinta, as well as his total dependence on Sugriwa and his monkey army to build a causeway to Alengka and then launch the final onslaught on Rahwana and his allies. Furthermore, as I have discussed, Sindhunata suggests that it is through the suffering and the humility of the monkeys, and their acute awareness of their station in life as titah, creations of God, that the arrogance and evil of Rahwana will be overcome. The final scene of the novel, depicting young monkey and ogre children playing together in blissful ignorance of the fate of either their parents or of Rahwana, Rama and Sinta, foreshadows an optimistic and egalitarian future for the descendants of the characters of the Ramayana, and thus for Indonesia itself.

In viewing Anak Bajang as a metaphor for the Indonesian nation, the poetic style of the novel merges the "ugly" state of the rakyat under the Suharto regime with the hope of a "beautiful" and "new" Indonesia emerging from within the very heart of the New Order. According to Sindhunata,

... poetry has the most freedom to remove itself as far as possible from the empirical realities that ensure that "ugliness" stays as "ugliness." Poetry needs to discover that "ugliness," then "purify" it from elements such as uncertainty, formlessness, ephemerality and randomness, and then embody all these aspects in a new form of beauty. ${ }^{70}$

I have already pointed to the shifting emphasis amongst Indonesian writers between "straight" reworkings of the Ramayana and humorous and ironic interpretations, in which "the evil king," Suharto, is satirized. Sindhunata's novel, rhetorically enacting a mobilization of the hitherto marginalized monkeys masses though it does, is in a sense a "straight" reading of the Ramayana, like Soebadio's Politik Dosomuko. The following texts which I discuss do not take the Ramayana seriously in its own right at all, preferring instead to use it as a springboard for humorous parody and scathing social and political satire.

\section{Sinta and the New Order "Social Contract" in Whani Darmawan's "Kabesmen"}

In late 1997 and throughout 1998, soon after the onset of the Asian economic crisis, a significant number of short stories, poems, plays, and newspaper columns featuring

\footnotetext{
69 "Raja dan rakyat itu harus wengku winengku, rangkul-merangkul, pangku memangku, seperti singa dan hutan, seperti Abimanyu dan Petruk." Ibid., p. 150.

70 "puisi yang paling mempunyai kebebasan untuk menarik diri sejauh mungkin dari realita-realita empiris yang mengikat kejelekan itu sebagai kejelekan. Puisi perlu menemukan kejelekan itu, lalu "menyucikan" kejelekan itu dari unsur-unsurnya seperti ketidakmenentuan, ketidakbentukan, kefanaan dan keserbakebetulan, lalu mengidealisasikan semuanya itu ke dalam bentuk keindahan baru." Sindhunata, "Semar dan Estetika Kejelekan," p. 218.
} 
Ramayana stories and characters appeared. ${ }^{71}$ Examples of literary allusions to the Ramayana in 1997 and 1998 include Made Adnanya Ole's short story, "Rahasia Gambuh" (The Secret of Gambuh), (1997)72; Sriyono's short story, "Culik," (Kidnap) (1998) ${ }^{73}$; Nano Riantiarno's play, Opera Hanoman (Hanoman's Opera), 199874; Soni Farid Maulana's poem, "Sepucuk Surat Sita Sebelum Labuh Pati," (A Letter From Sita Before Her Ordeal) (1998) ${ }^{75}$; Putu Wijaya's play, Ngeh (Got It), 199876; and Ki Sunu's series of Ramayana parodies appearing in the Sunday edition of the Surabaya-based newspaper, Jawa Pos, from September 1997 to January 1999. Several years after Suharto's resignation, Ramayana characters and motifs continue to proliferate in various literary forms, such as in Sunaryono Basuki Ks.'s short story, "Gadis Kecil dan Mahkota Raja" (A Small Girl and the King's Crown), (1999) ${ }^{77}$; the title poem of Asep S. Sambodja's collection, Menjelma Rahwana (Becoming Rahwana) (1999) ${ }^{78}$; Linus Suryadi's unpublished novel Kisah Dewi Anjani (The Tale of Dewi Anjani), which was read as a performance (accompanied by a gamelan orchestra) in Yogyakarta on February 10-11, 1999, just before Linus passed away; Bonari Nabonenar's "Tata" $(2001)^{79}$ and Seno Gumira Ajidarma's forthcoming novel based on the characters and tales of the Ramayana. ${ }^{80}$

One of the Ramayana-based short stories appearing in early 1998, "Kabesmen" (On Fire), ${ }^{81}$ was written by Whani Darmawan, a young playwright and writer based in Yogyakarta.82 In this short story, when Hanoman is sent to Alengka to ascertain the welfare of Sinta, he discovers more than he bargained for: a naked Sinta sleeping with an equally naked Rahwana. Exhaustive in its unflattering portrayal of both Rahwana and Sinta, "Kabesmen" is a savage indictment of the hypocritical selfishness and corruption of Indonesia's privileged elite. Consider the following passage, depicting Sinta's rationale for what she is doing:

\footnotetext{
71 Of course, the following observations merely update G. J. Resink's visionary article, "From the Old Mahabaharata to the New Ramayana-Order," Bijdragen tot de Taal-, Land-en Volkenkunde 131,2/3 (1975): 214-235.

72 Made Adnanya Ole, "Rahasia Gambuh," Horison 32,10 (1997): 25-30.

73 Sriyono, "Culik," Kedaulatan Rakyat, May 3, 1998.

74 Nano Riantiarno, "Opera Hanoman" (unpublished, 1998).

75 "Sepucuk Surat Sita Sebelum Labuh Pati" was first written in 1998 and published in Soni Farid Maulana, Kita Lahir Sebagai Dongengan (Magelang: IndonesiaTera, 2000), pp. 66-67. Note that labuh pati is a Javanese term for a scene in the Ramayana where after her rescue Sinta must prove her purity by ascending a burning pyre. Some versions say that she is corrimed by the fire, others that she emerges unharmed.

76 Putu Wijaya, "Ngeh" (unpublished, 1998).

77 Sunaryono Basuki Ks., "Gadis Kecil dan Mahkota Raja," Jawa Pos, May 21, 1999.

78 Asep S. Sambodja, Menjelma Rahwana (Jakarta: Komunitas Bambu, 1999), p. 12.

79 Bonari Nabonenar, "Tata," Suara Merdeka, January 8, 2001.

80 Interview with Seno Gumira Ajidarma, Jakarta, November 17, 2000.

81 Whani Darmawan, "Kabesmen," Basis 47,1-2 (January-February 1998): 82-87.

82 Under the guidance and encouragement of poet and playwright Emha Ainun Nadjib, Whani has been writing and performing in both Javanese and Indonesian for almost ten years. Born in Yogyakarta on May 24,1966 , Whani has experimented with wayang characters and plots on a number of occasions, most notably in his 1998 theatre production, Karno Tanding.
} 
For her, people should use every moment to renew themselves. The past is best treated as a time forever lost. Sinta wanted to forge a career as a famous woman, without caring what sort of career. As a consequence, she decided not to regret her past history. For her, loyalty and fortitude had changed their meanings: now they were synonyms for stupidity and uselessness. Sinta had decided to share her bed with Rahwana even though she didn't love him.

"Your charade is brilliant, Sinta. What a success," puffed a tired Rahwana. "You're my watermelon."

"And you are my golden banana. Go and publicize this refusal of mine, so that the pakem ${ }^{83}$ plots about us remains unchanged, forever closing the door to democratic values. So go and angrily fume away with your ten faces so that the world may keep on regarding me as a pure woman and keep on regarding you as the embodiment of evil. A world that rejects revolution is sure to accept such an idol as this."

Rahwana immediately burst into laughter. ${ }^{84}$

This passage shares a lot in common with Yudhistira's satire of Jakarta's urban elite in the late 1970s, especially in the malicious contradiction between the protagonists' stilted language and their modern bourgeois behavior. For example, Sinta and Rahwana refer to each other with stilted pronouns such as "Engkau" ("you," or even "thy"), "Dinda" (an affectionate "literary" form of address for a wife or lover), and "Kanda" (an affectionate "literary" form of address for a husband or lover). Coupled with ludicrous terms of affection such as "my golden banana" and "my watermelon," these pronouns are used as obvious forms of mockery, highlighting the hypocritical nature of the text's protagonists. This is especially so for Sinta, who seeks comfort and corruption whilst deluding the outside world with her sandiwara (charade), which she uses to maintain the myth of her purity. Of course, this charade, besides making Rahwana laugh, does not fool Hanoman at all.

83 Javanese puppeteers make a distinction between pakem [trunk] and carangan [branch] tales of the wayang shadow puppet theatre. Although the boundary between the two types of stories is hazy and there is much disagreement over which stories can be defined as trunk or branch, pakem stories are generally regarded as those which closely follow the relatively fixed outlines of the Indian Mahabharata and Ramayana tales. The carangan tales are derived from the pakem stories, but they lead away from the Mahabharata and Ramayana, giving shadow puppeteers greater opportunity to incorporate new material into the wayang tradition. See Laurie J. Sears, Shadows of Empire: Colonial Discourse and Javanese Tales (Durham and London: Duke University Press, 1996), pp. 233-234.

84 “Baginya, dalam setiap detik manusia senantiasa harus memperbarui dirinya. Masa lalu sebaiknya diperlakukan sebagai masa yang hilang. Sinta ingin mengejar karier sebagai wanita ternama, tak peduli sebagai apa. Karenanya, ia memutuskan untuk tidak menyesali pada sejarah yang sudah dilaluinya. Kesetiaan dan ketahanan baginya telah berubah makna, semacam kebodohan dan kesia-siaan. Sinta telah memutuskan bercinta dengan Rahwana meski ia tak mencintainya."

"Begitu hebatnya sandiwaramu, Dinda. Betapa berhasilnya." Engah Rahwana dalam lunglainya. "Engkaulah semangkaku, Dinda."

“Engkaulah pisang ambonku, Kanda. Terus kobarkanlah penolakanku ini. Agar pakem-pakem cerita tentang kita tak pernah berubah, tak pernah memberi ceruk ruang demokrasi nilai. Terus beranglah dengan muka sepuluhmu agar dunia tetap mengenalku sebagai wanita yang suci, agar menganggapmu tetap sebagai Durjana. Dunia yang menolak revolusi pasti menyetujui berhala ini."

"Rahwana seketika menyalakkan tawanya." Whani Darmawan, "Kabesmen," p. 85. 
Whani's biting denouement to the story, in which small ogre-tusks appear to emerge from the corners of Sinta's mouth, suggests that our so-called heroine is not only in cahoots with Rahwana, but has even become a female version of her ogre-lover. If Sinta were to be treated as a metaphor for the Indonesian nation and its people, as she so often is, ${ }^{85}$ one could argue that Sinta's marriage-of-convenience with Rahwana represents what has been termed the New Order "social contract." As a consequence of Indonesia's high levels of economic growth during the first few decades of Suharto's regime, an unspoken "social contract" came into being, whereby the upper and middle classes ceded their political rights in exchange for social order and the opportunity to pursue their dreams of upward economic mobility relatively unhindered. ${ }^{86}$ Using Darmawan's story as a metaphor for the societal tensions of the Indonesian nation, in effect what we can see is that Sinta, a representation of the increasingly prosperous middle classes, is co-opted by Rahwana, who can be considered as a representation of the New Order regime. The next two stories to be discussed also use the Ramayana as a basis for satirical comment, with even more emphasis on the link between Rahwana and the New Order.

\section{Pipit Rochijat's "President Dosomuko": a Parody of Suharto}

Pipit R. K, or Pipit Rochijat Kartawidjaja, is an Indonesian writer, émigré and activist based in West Berlin. ${ }^{87}$ This discussion will be based on the first story of Pipit's one and only literary publication, a collection of brilliantly satirical wayang parodies entitled Baratayuda di Negeri Antah Berantah (The Baratayuda in Never-Never Land) (1993), which was first written in the early 1980s. ${ }^{88}$ With the exception of an unpublished paper by Amrih Widodo, as far as I am aware until now Pipit's extremely humorous collection appears to have failed to attract any major scholarly attention. ${ }^{89}$ One explanation for this is that in an artistic or literary sense Pipit's stories are little more than seditious parody. Another explanation for the lack of critical attention could be that when compared to the richness of the wayang's theatrical effect in performance, the presentation of plot, action, and characterization through written words alone may seem to be but a pale imitation of the real thing. According to Amrih,

In writing these stories, the author does not seem to think about wayang performance-the night long presentations accompanied by the gamelan ensemble. Gamelan - the Javanese music orchestra-is never mentioned. There is

\footnotetext{
85 See earlier comments in this article, as well as A. S. Laksana's short story, "Air Mata Dewi Shinta," in Podium Detik (Yogyakarta: Sipress, 1995), pp. 49-52.

86 See Edward Aspinall, Gerry van Klinken, and Herb Feith, "Introduction," The Last Days of President Suharto, ed. Edward Aspinall, Herb Feith and Gerry van Klinken (Clayton: Monash Asia Institute, 1999), pp. ii-iii.

87 For more on the colorful background to Pipit, see Pipit Rochijat, "Am I PKI or Non-PKI?" (translated with an Afterword by Benedict Anderson), Indonesia 40 (1985): 37-56.

88 Pipit Rochijat, Baratayuda di Negeri Antah Berantah.

89 See Amrih Widodo, "'Wayang' Revisited: The Politics of Language of a New Order Student," (unpublished manuscript, 1988), pp. 1-27. Pipit and his writing is briefly discussed in Benedict Anderson, The Spectre of Comparisons: Nationalism, Southeast Asia and the World (London and New York: Verso, 1998), pp. 293-295.
} 
no indication that Pipit's wayang stories are to be performed, or are in any way related to ceremonies or rituals of which wayang is usually a part. This is wayang without a stage, without spectators, without musical accompaniment and without ritual significance in the conventional sense. ${ }^{90}$

Clearly, Pipit's "wayang," if indeed it can even be called "wayang," is totally removed from the theatrical and ritual dimensions of a wayang performance. After spending much of the last three decades in West Berlin, with a number of those years without his Indonesian passport, 91 it would be an understatement to say that Pipit has not seen very many wayang performances since leaving Indonesia. Furthermore, Pipit's style of wayang story-telling derives from the wayang comics of R. A. Kosasih, of which Pipit is an avid reader, and the comics of Kho Peng Ho, based on the "Tales of the Three Kingdoms." 92

Nevertheless, in "Dan Apalah Artinya Kejayaan Itu, Kalow Toh Tak Mampu Melawan Guna-guna?" (And What's the Point of Being On Top, If You Still Can't Fight Black Magic?) Pipit uses humorous devices suspiciously similar to the standard narrative tools of a dalang, such as plesetan and kérata basa, or "word play."93 However, whether the techniques used are derived from an oral or literary tradition, ultimately the aim of Pipit's humor is to ensure that his version of Dasamuka - that is, President Dosomuko-is undoubtedly representing, and humiliating, none other than former President Suharto. Consider the following passage:

After General Dosomuko succeeded in seizing power of the Republic of Lokapala, he promptly promoted himself to President and changed the name of the Republic of Lokapala to the Republic of Ngalengkodirjo. He chose this unique name deliberately as a warning for everybody. That is, to warn them that with the rise of General Dosomuko to President, the Republic of Ngalengkodirjo opened a new page in history. Because, according to the story he made up, Ngalengkodirjo means Ngalahke Koboi Dadi Rojo ("Defeating the Cowboys in Order to Become King") - in contrast to Lokapala ("the Lokasi"94 of the Head of State's Henchmen"). 95

By using kérata basa to explicate the etymology of the kingdoms of Ngalengkodirjo and Lokapala, President Dosomuko's move to change the name of Lokapala to Ngalengkodirjo strongly resembles Suharto's manipulative naming of Sukarno's

\footnotetext{
90 Amrih, "Wayang' Revisited," p. 14.

91 See "Ditawari Suaka Politik, Masih Cinta Indonesia," Jawa Pos, July 19, 1998.

$92 \mathrm{My}$ thanks to Ben Anderson for pointing this out to me.

93 Pipit Rochijat, "Dan Apalah Artinya Kejayaan Itu, Kalow Toh Tak Mampu Melawan Guna-guna," in Baratayuda de Negeri Antah Berantah, pp. 1-3.

94 Lokasi here refers to the New Order government's habit of formally concentrating places of prostitution and gambling in one neighborhood, a process called "localization."

95 "Setelah Jenderal Dosomuko berhasil merebut kekuasaan di Republik Lokapala, maka ia pun mengangkat diri menjadi presiden dan mengubah nama Republik Lokapala menjadi Republik Ngalengkodirjo. Nama unik ini sengaja dipilih untuk mengingatkan penduduknya. Bahwa dengan berkuasanya Jenderal Dosomuko menjadi presiden, Republik Ngalengkodirjo itu membuka lembaran sejarah baru. Sebab, menurut dongengnya, Ngalengkodirjo berarti Ngalahke Koboi Dadi Rojo ("Defeating the Cowboys in Order to Become King")- in contrast to the Republic of "the Lokasi of the Head of State's Henchmen" (Lokapala)." Pipit Rochijat, "Dan Apalah Artinya Kejayaan," p. 1.
} 
Indonesia as the "Old Order" and post-Sukarno Indonesia as the "New Order."96 Pipit's explication of the meaning of Lokapala as "Lokasinya Antek Kepala Negara" (The Lokasi of the Head of State's Henchmen) and Ngalengkodirjo as "Ngalahke Koboi Dadi Rojo" (Defeating the Cowboys in Order to Become King) also cleverly alludes to the violent fashion in which Suharto came to power. That is, Suharto became "king" by "defeating" the "cowboys," which could easily be taken to mean the ousting of Sukarno and the massacre of his antek, a word with a 1960s flavor used to refer to "henchmen" or "cronies." In this context, there is no doubt that Pipit is referring to Sukarno and the Communists and Sukarnoists.

Other parallels are drawn between President Dosomuko and Suharto. For example, just like Suharto, the power of President Dosomuko is based on military might, social repression, and the corruption of key public figures and institutions such as his political advisors and the legal profession. However, as a leader, President Dosomuko is a laughable failure. No longer is he an all-powerful mythological king with the world at his feet. In Pipit's hands, Dosomuko's presidency is a sham, and in terms of running the nation he is totally dependent on his advisors, not to mention his military thugs. Furthermore, as will become evident in the "climax" of Pipit's opening wayang narrative, the greater President Dosomuko's thirst for power, the greater his powerlessness:

Despite the fact that President Dosomuko had supernatural powers and couldn't be done in, he also had a weakness. According to palace whispers, he was once put under a spell by a famous dukun, ${ }^{97}$ Maha Ageng, the result being that he needed to rest his vital organ for weeks on end, as it had swollen to the size of his thigh.

Naturally, President Dosomuko's life became hell. Just imagine: even after picking up Dewi Sinta, the disco queen, he couldn't even get a kiss. Why? Well, she would only start screaming, probably thinking that the president's leg was in the wrong place. This was of course nothing compared to his wife, Nyai Dosomuko, who for some time had been on a full-scale rampage, due to the fact that the President had been unable to satisfy her natural urges. As a result, the President became stressed out. After all, even if he wanted to masturbate, it was impossible. Oh my God, how would he grip the thing?

It was this bitter experience that finally led President Dosomuko to promote Maha Ageng and all the other famous dukun as his personal bodyguards. Since then he has always been on his guard, in case his political opponents might fight dirty and use black magic.

Thus President Dosomuko also knows that his personal safety cannot be fully guaranteed. His vital organ swelling up is just one indication of this. Luckily Maha Ageng is easily bribed. Of course, Maha Ageng has no idealism whatsoever.

\footnotetext{
96 For more on kérata basa, see Ward Keeler, Javanese Shadow Plays, Javanese Selves (Princeton: Princeton University Press, 1987), pp. 223, 248, 250, 251-253; and A. L. Becker, "Text-Building, Epistemology, and Aesthetics in Javanese Shadow Theatre," in The Imagination of Reality, eds. A. L. Becker and A. A. Yengoyan (Norwood, New Jersey: Ablex, 1979), pp. 236-237.

97 A dukun is defined by Ward Keeler as "a magic specialist to whom people turn for cures, advice, and other mystical assistance." Keeler, Javanese Shadow Plays, Javanese Selves, p. 269.
} 
But, what will happen if new dukun emerge-more powerful than Maha Ageng, and with a high idealism to boot-who decide to side with the President's political opponents? ${ }^{98}$

The attack on Suharto in this tale is twofold. As I have already tried to show, Suharto is portrayed and denounced as an evil totalitarian dictator, comfortable with immorality, brutality, repression, and manipulation. ${ }^{99}$ The humorous language of the tale, characterized by plesetan, kérata basa, and Pipit's linguistic "comic-to-the-eye" idiosyncrasies such as the amusing spelling of words ending in "-au" like "kalau" and "atau" as "kalow" and "atow," may present a softer edge to Pipit's satire. However, the passage above, totally humiliating Suharto, shows us that Pipit's humor is deadly serious.

This leads us to the second prong of Pipit's attack, which is even more radical. ${ }^{100}$ Referring to President Dosomuko's massively engorged penis as an alat vital, the prim officialese "vital organ," Pipit's tale is a low blow, a dig not only at New Order Indonesian and Suharto's manhood, but also his wife, who is depicted as a sexobsessed vamp. The humiliating image of President Dosomuko unable to masturbate also hits the President below the belt, in a strikingly crude way stripping the emperor's clothes and exposing to public gaze his normally private activities. Considering the advanced age of Suharto and his wife at the time, Pipit's tale is even more offensive in its excess of intimacy. In the sense that Pipit's story depicts President Dosomuko as impotent and powerless, completely at the mercy of outside forces such as dukun working on the side of "political opponents," it also foreshadows later events, in

98 "Walowpun Presiden Dosomuko itu sakti mandraguna dan tak bisa dimampusin, ia punya kelemahan juga. Sebab, menurut desas-desus istana, ia pernah diguna-guna oleh seorang dukun terkenal, yaitu Maha Ageng, sehingga alat vitalnya pun harus berminggu-minggu mengaso sebab menjadi bengkak segede paha kakinya."

"Tentu saja, Presiden Dasomuko menjadi sengsara. Coba: Dewi Sinta yang ratu disko dan baru digaet itu tak bisa dicumbui. Wah, wah, dia bisa jerit-jerit karena kaki Presiden Dosomuko dikira salah ngamar. Belum lagi bininya, Nyai Dosomuko, jadi ngamuk-ngamuk, sebab kebutuhannya tak bisa dipenuhi oleh Presiden Dosomuko. Makanya, ia pun jadi syaraf. Habis, mau onani juga tak mungkin. Olala, gimana dia harus megang?"

"Pengalaman pahit itulah yang akhirnya menyuruh Presiden Dosomuko mengangkat Maha Ageng dan dukun-dukun terkenal lainnya sebagai pengawal pribadinya. Dia selalu was-was, kalow-kalow lawanlawan politiknya main curang dan menggunakan metode guna-guna."

"Presiden Dosomuko pun tahu, bahwa jaminan keamanan seratus persen tak bisa dicapai. Dan membengkaknya alat vitalnya cuma merupakan satu bukti saja. Untung Maha Ageng bisa dibujuk. Sebab, Maha Ageng tak punya idealisme sama sekali."

"Tapi, apa yang bekal terjadi, kalow muncul dukun-dukun baru yang lebih hebat ketimbang Maha Ageng dan beridealisme tinggi lalu memihak lawan-lawan politiknya?" Pipit R. K., "Dan Apalah Artinya Kejayaan Itu, Kalow Toh Tak Mampu Melawan Guna-guna," pp. 2-3.

99 A similar perspective is presented in Yudhistira's collection of short stories, Wawancara Dengan Rahwana (Jakarta: Grafitipers, 1982), pp. 65-68. In the title story of the collection, the deceased Rahwana is interviewed in the afterlife by a particularly keen journalist, Sanjaya. Yudhistira's Rahwana believes that traces of his evil essence have infiltrated all authoritarian leaders, even suggesting that "Seorang penguasa yang baik harus sadis" (A good leader must be sadistic). Ibid., p. 68.

100 The following analysis was inspired by J. M. Coetzee's analysis of Breyton Breytenbach's 1972 poem, "Letter from Foreign Parts to Butcher," which was banned for distribution in South Africa due to its references to the then Prime Minister, Balthazar John Forster. See Coetzee, Giving Offense, pp. 215-232. 
particular the well-documented economic and political events of late 1997 and 1998. In effect, Pipit, like one of his fictional $d u k u n$, claims a power that Suharto, even as self-proclaimed Bapak Pembangunan (Father of Construction), lacked-the power to "construct" the future. The final text to be discussed, a short story by Martin Suhartono, reveals precisely what the future held for Suharto: his enforced "abdication" from the presidency, an act otherwise known as lengser keprabon.

\section{Revisiting Lengser Keprabon: Martin Suhartono's “Lengsernya Rahwana"}

In a manner highly reminiscent of Pipit's insolent parody of Suharto, Martin Suhartono's "Lengsernya Rahwana" (The Abdication of Rahwana), published in July 1998, is another highly personalized attack on the legacies of Suharto's authoritarian rule. ${ }^{101}$ As with Pipit's Baratayuda di Negeri Antah Berantah, the importance of Martin's story lies not so much in its artistic or literary merit, but rather in the way in which it displays the symptoms of the times and the changing society in which it appears. The story's title is the most obvious clue that this tale is concerned, at different levels, with representing something of the truth and reality of late New Order Indonesia. Of course, "Lengsernya Rahwana" is easily recognized as a play on Suharto's much-discussed intention to "lengser keprabon, madeg pandhita," or "abdicate" the presidency at the appropriate time. ${ }^{102}$

Using a flashback technique popularized by a number of Java's more progressive dalang, Martin's story opens with the death of Rahwana, and then through a shift in time-frame it recounts the birth of Rahwana and the series of misadventures leading to his death. Yet the story is by no means linear, and it often digresses into streams of highly politicized wayang exegesis and thinly-veiled allusions to Suharto and his regime. Consider the tongue-in-cheek combination of wayang discourse and references to Suharto and his governance in the story's dramatic opening passage:

The ground shook, the sky thundered, the mountains shuddered, and the sea churned when Rahwana died. The entire cosmos was moved when Rahwana's ten heads were chopped off one by one and hit the ground. Nature was moved not because she was sad, of course. If she could, she would have sung out aloud Sorak-Sorak Bergembira [Shouts of Happiness], just like the majority of the people of the Kingdom of Nusantara when The Lord was dethroned by a landslide. The difference between The Lord and Rahwana was that Rahwana had the $A j i$ Pancasona, whereas The Lord had the Aji Pancasila. ${ }^{103}$

Stylistically, "Lengsernya Rahwana" is dominated by the wayang medium, and in particular the language and narrative techniques of wayang shadow puppeteers. Common wayang terms and expressions are evoked and manipulated as a means of

101 Martin Suhartono, "Lengsernya Rahwana," Basis 47,7-8 (July-August 1998): 63-68.

102 See Benedict Anderson, "A Javanese King Talks of his End," Inside Indonesia 54 (April-June 1998): 1617; and Franz Magnis-Suseno, "Langsir Keprabon."

103 "Bumi gonjang-ganjing, langit kerlap-kerlip, gunung morat-marit, dan laut mbolak-mbalik ketika Rahwana binasa. Seluruh alam semesta bergolak sewaktu sepuluh kepala Rahwana copot satu per satu menimpa bumi. Alam bergejolak bukan karena sedih, tentu saja. Seandainya bisa, alam raya akan bernyanyi SorakSorak Bergembira, sama seperti mayoritas tunggal warga kerajaan daripada Nusantara sewaktu Sang Prabu longsor keprabon. Bedanya, Rahwana mengandalkan Aji Pancasona, sedangkan sang Prabu Aji Pancasila." Martin Suhartono, "Lengsernya Rahwana," p. 63. 
expressing highly confrontational sociopolitical commentary. For example, as in the passage above, it is stated that Rahwana is protected by the Aji Pancasona, which as noted earlier is a powerful boon whereby as long as its possessor is in contact with the ground, he or she is unable to die. "Pancasona" can also be read as a spiteful pun on the Pancasila (The Five Principles, the five philosophical principles underlying the Indonesian state). Considering that "sona" is literary Javanese for "dog," "Pancasona" can also mean "The Five Dogs." Meanwhile in contrast to Rahwana, "Sang Prabu" (The Lord)-a reference to Sukarno, who invented the Pancasila in June 1945--was protected by another magic weapon, the Aji Pancasila. Also in the same passage, the ungrammatical placing of daripada, which is a direct translation of the Javanese in which Suharto thinks, and the pun on longsor keprabon (which literally means "landsliding off the throne" instead of "abdicating the throne") satirizes Suharto's wellpublicized linguistic idiosyncrasies, and thus immediately identifies Suharto as the main polemical target of the story. Later, Martin is even more strident in his attack upon Suharto, again using word play to emphasize his malicious intent. For example, toying with the similarity between pembangunan (construction) and pembangkrutan (bankruptcy), the narrator observes that "Whilst before Rahwana was once promoted as 'Father of Alengkadireja Construction,' now he'll only be denounced as 'Father of Alengkadireja Bankruptcy'!"104

In combination with the self-conscious manipulation of wayang terminology and both Javanese and Indonesian expressions, the stylistic presentation of "Lengsernya Rahwana" is imbued with the chaotic realities of Indonesia's era reformasi (pro-Reform era). This is apparent in Martin's eclectic mixture of essayistic discourse, quotes, footnotes, and translations, all included within the body of the text itself. Literary versions of the Ramayana cycle by Indonesian writers such as Herman Pratikto ${ }^{105}$ and Sindhunata are quoted from time to time, as well as the analyses of some of the essays from a Ramayana conference held in Yogyakarta in early 1998. ${ }^{106}$ The unabashed mixture of essay and fiction as a narrative technique has much in common with the style and purpose of Soebadio's Politik Dosomuko Rezim Orde Baru, which was discussed earlier. In homage to Soebadio's text, the narrator of "Lengsernya Rahwana" even quotes in full Soebadio's famous ten characteristics of "Dosomuko's Political System." Ultimately, with quotation after quotation interspersed with translations, puns on New Order discourse, facile asides, and overly-politicized interpretations of Rahwana's life-story, any pretence to fictionality is abandoned, just as the "truth" behind Suharto and his regime is uncovered.

One could argue that the eclectic jumble of fact, fiction, and quotation in "Lengsernya Rahwana" embodies what Michael Bodden has loosely termed as "the postmodernist style of the pro-Reform era-including a 'poetic collage report' format

104 "Padahal dulu Rahwana pernah diangkat sebagai 'Bapak Pembangunan Alengkadireja,' kini ia hanya akan dihujat sebagai ‘Bapak Pembangkrutan Alengkadireja'!” Ibid., p. 67.

105 Herman Pratikto wrote a 'straight' retelling of the Ramayana cycle of tales in Indonesian entitled Ramayana (Jakarta: Penerbit Widjaya, 1962).

106 The proceedings of this conference are published in Sarworo Soeprapto and Dra. Sri Harti Widyastuti, eds., Ramayana: Transformasi, Pengembangan dan Masa Depannya (Yogyakarta: Lembaga Studi Jawa, 1998). 
without fixed characters or linear plots." 107 However, the pastiche of "Lengsernya Rahwana" is not merely a reflection of the social and political chaos of the times, but also a pointer to the development of a new conceptualization of what it means to be a meaningful citizen of Indonesia in the post-Suharto era. After Alengka is destroyed and Rahwana defeated, his younger brother Wibisana is counseled by Rama. He is told to move beyond the past, and to look to the future, which will be of his own making. Rama explains that Wibisana's task is to rebuild the ravaged Alengka into a peaceful, prosperous, and just society, using the "Astabrata," or "eight steps" of leadership, "just like with The Seven Habits by that Stephen Covey, 108 but even better because this isn't just seven steps but eight!"109 Unlike Stephen Covey's pop psychology, the "Astabrata" is a mystical passage included in a nineteenth-century Javanese text based on the Ramayana, Serat Rama, written by Yasadipura I and derived from an old Indian Sanskrit text. ${ }^{110}$ Martin's version of the "Astabrata" is "updated" to suit the pro-Reform context. Each step involves following the example of a wayang god, including Indra's benevolent devotion to the provision of social welfare without resorting to nepotisme (nepotism) or koncoism (cronyism); Yama's righteous desire to establish a fair legal system without recourse to kidnappings and murder; Surya's love of learning and disdain for propaganda and indoctrination; Chandra's embodiment of morality and equanimity; Bayu's intimacy with the aspirations of the masses without resorting to the use of intel (state intelligence agents); Kuwera's ability to provide an abundance of employment and sembako (the nine basic items of food and services); Baruna's dislike of violent and lawless behavior, especially at the hands of preman and gali (petty criminals and thugs) hired and equipped by the powers-that-be; and Agni's ability to eliminate any stumbling blocks against the establishment of social and political justice, such as politik adu domba (divide and conquer politics). In Martin's version of the "Astabrata," Pertiwi, or the Goddess of the Earth, can act as a replacement for any of the other gods. This is because Pertiwi "supports and protects anybody fairly without any sort of KKN (Corruption, Collusion and Nepotism)."111

After Rama's explanation of the eight "steps" needed in his nation's recovery, Wibisana is enlightened, emboldened, and ready to face an uncertain future with a new confidence. It appears that in "Lengsernya Rahwana" the transition to a new society must involve the leadership of an appropriate ksatria leader, such as an enlightened Wibisana. However, by the same token, the path ahead involves at least one major conceptual "rupture" or modification to the Ramayana's ksatria-orientation: the empowerment of the hitherto marginalized subordinate masses. As a reflection of this, not unlike the optimistic denouement of Anak Bajang, the monkeys are portrayed as the

${ }^{107}$ Michael H. Bodden, "Notes on the Culture of the 'Reformasi Era,'" (unpublished manuscript, 1999), p. 16.

108 Stephen R. Covey is the author of The Seven Habits of Highly Effective People (New York: Simon and Schuster, 1989), as well as several other books on the psychological aspects of personal and financial success.

109 "mirip dengan The Seven Habits dari Stephen Covey itu, tapi lebih ampu lagi karena ini bukan cuma tujuh melainkan delapan!" Martin Suhartono, "Lengsernya Rahwana," p. 67.

110 Soemarsaid, State and Statecraft in Old Java, Appendix 3. See also Wahyati Pradipta, "Ajaran Kepemimpinan Astabrata," in Ramayana: Transformasi, Pengembangan dan Masa Depannya, pp. 154-165. 111 "menunjang dan melindungi siapa saja sama rata tanpa KKN (Korupsi, Kolusi, dan Nepotisme) apa pun!" Martin Suhartono, "Lengsernya Rahwana," p. 68. 
final image of "Lengsernya Rahwana." On this occasion the monkeys are specifically aligned with the pro-Reform university students:

Every time that the monkeys who represent nature are oppressed and forgotten, at that very moment Rahwana will be capable of shoving aside the three mountains that are pinning him down, and come back and resume his absolute rule unhindered. It's just the same with the students: if they are oppressed and forgotten in their every effort to bring about reformasi, at that very moment reformasi will be transformed into deformasi. ${ }^{112}$

Martin appears to suggest that the role of the monkeys in bringing about reformasi (and then ensuring that the gains of the reformasi movement are carried through to their logical conclusion) is crucial to the social development of the Indonesian nation. Furthermore, Martin is also warning us that Dasamuka, a metaphor for dictatorship and repression, can come back at any time if the "monkey masses" of Indonesia are not vigilant.

\section{"Anoman Obong"}

Both Martin Suhartono's and Sindhunata's focus on the monkeys in their reworking of the Ramayana epic has been complemented by the efforts of other writers, who have chosen to fictionalize other characters of the Ramayana, such as Rahwana, Rama, Sinta, Hanoman, and Wibisana. This by no means downgrades the monkeys' role as representations of ordinary Indonesians, and their role as discursive counters to Suharto's symbolic authority. Indeed, many Indonesians felt that Suharto's days were numbered from the very moment the catchy Javanese pop song "Anoman Obong" (Anoman Alight) appeared in 1996. The title of the song refers to one of the core classical episodes of the Ramayana epic, in which Hanoman slips into Rahwana's palace in Alengka in search of Sinta. In the words of the song itself,

Anoman the white monkey

Came to Sinta's prison to take her home

Captured by Indrajit and the Chief Minister

But Anoman was not a scared monkey. ${ }^{113}$

Unable to rescue Sinta, Hanoman is captured and condemned by Rahwana to be burned at the stake as a spy. Although the captive Hanoman is put to the stake, and his tail is set alight, he uses his supernatural powers to break his bonds. As he springs into the sky, the sparks from his burning tail burn all the roofs of Alengka, setting the whole city on fire. The 1996 song "Anoman Obong" was composed by the Javanese comedian Ranto Edi Gudel, initially recorded by Kawulo Alit, a group of buskers

112 "Setiap saat kera-kera yang mewakili alam ditindas dan dilupakan, saat itulah Rahwana akan mampu menyingkirkan ketiga gunung yang menghimpitnya dan kembali berkuasa merajalela, sama halnya bila para mahasiswa ditindas dan dilupakan dalam setiap usaha reformasi, saat itulah reformasi bakal berubah menjadi deformasi." Ibid.

113 Anoman si kethek putih/ Sowan tamane Sinta diajak mulih/ Konangan Indrajit lan Patih/ Ning Anoman ora wedi kethek. 
based in Solo, and popularized by dangdut ${ }^{114}$ singer Mamiek Melani. Much has been made of the song's symbolism, particularly in light of the fires, partly organized by Suharto's own henchmen, that were later to engulf shopping centers, houses, and buildings in Jakarta and Solo during the May riots of 1998. Consider the following lines, which, in referring to the fiery fate of Ngalengko (Alengka) and the presence of Togog and Bilung, the clown-servants of Rahwana, undeniably foreshadowed later events:

Oh, hey my goodness Ngalengko was burnt (was burnt, was burnt)

Togog and Bilung, oh, were both spellbound and speechless

Big buildings were all burnt to cinders (to cinders, to cinders)

Dosomuko died roaring and crying. ${ }^{115}$

One well-known "paranormal" psychic based in Solo, Bang To Es, felt gelisah (unsettled) as soon as he heard these lyrics, and his fears dramatically increased upon hearing that the Indonesian government was commissioning a series of Rama Tambak performances. ${ }^{116}$ From that moment he was in no doubt that "Anoman Obong" was "a sign from God," warning of impending disaster. In light of the mass destruction and large loss of life experienced in the May riots alone, his fears were well-founded.

Jan Mrázek has observed that in 1996 and 1997 "Anoman Obong" was played in almost every wayang performance that he attended, and I can add that in the first half of 1998 this song was performed in almost all of the wayang performances that I happened to attend. Mrázek quoted a 1997 newspaper article to describe the incredible popularity of this song:

About "Anoman Obong" itself: it is not too much to crown it as one of the most popular songs in the last two years, even when compared with songs in the [national] pop Indonesia genre [that is, not only with Javanese pop]. How could it be otherwise; from adult people, to street children begging on buses, all really know by heart the lyrics...117

According to Frans SP, the manager and producer of Mamiek Melani's dangdut group, OM Ken Arok, the album containing "Anoman Obong" had sold 400,000 copies by late $1998 .{ }^{118}$ For a song in a regional language, this is a phenomenal amount. ${ }^{119}$ What's more, these sales do not include all the other versions that have appeared in genres ranging from gendhing Jawa (gamelan music) and tembang Jawa (Javanese pop) to uptempo styles of dance music such as electronic house music.

114 For more on dangdut, which is a hybrid form of popular music, see Krishna Sen and David T. Hill, Media, Culture, and Politics in Indonesia (Melbourne: Oxford University Press, 2000), pp. 164-193.

115 Ee... ladalah Ngalengka diobong (diobong, diobong)/ Togog Bilung wah ah o... padha pating domblong/Omah gedhe padha dadi areng (dadi areng, dadi areng)/ Dosomuko mati gereng-gereng.

116 "'Anoman Obong' di Mata Paranormal," Suara Merdeka, May 26, 1998.

117 Muliawan Hamdani SE, "Lagu Pop Jawa Riwayatmu Kini," Suara Merdeka, July 24, 1997, quoted in Jan Mrázek, "Javanese Wayang Kulit in the Times of Comedy: Clown Scenes, Innovation, and the Performance's Being in the Present World (Part One)" Indonesia 68 (October 1999): 38-128.

118 "Frans SP Cari Produser Lain untuk Produksi 'Brantayuda,'” Suara Merdeka, September 1, 1998.

${ }^{119} \mathrm{My}$ thanks to Edwin Jurriens, a Leiden University researcher working on the electronic media in Indonesia, for confirming this statement. 
Of course, in terms of sales, popularity and audience reach, if "Anoman Obong" were to be placed alongside its fellow interpretations of the Ramayana, the literary texts discussed in this article, there would be no comparison. For example, the cultural studies magazine responsible for publishing "Kabesmen" and "Lengsernya Rahwana," Basis, only has a print run of five thousand for each edition. ${ }^{120}$ As noted earlier, Politik Dosomuko Rezim Orde Baru was actually banned and removed from circulation for a short period in 1998. Since the ban was lifted soon after the resignation of Suharto, copies for sale have proven to be almost impossible to find. Meanwhile, although Baratayuda di Negeri Antah Berantah, in either its manuscript or published form, has quietly achieved cult status amongst Indonesianists and Indonesian intellectuals and activists for almost twenty years, it is virtually impossible to calculate exactly how many people have actually read it. According to Maier, literary texts in Indonesia usually sell no more than four or five thousand copies over a long period of time. ${ }^{121}$ Based on the assumption that three or four people read each copy, arguably no more than twenty thousand people have read Pipit's text. The most popular of the texts discussed here, Anak Bajang Menggiring Angin, was initially serialized in the authoritative Indonesian newspaper, Kompas, and since its publication in 1983 it has gone through four editions, almost a best-seller by Indonesian standards.

Even if texts such as Anak Bajang have sold, say, thirty or forty thousand copies, some might argue that, politically, texts such as these have not proven to be anything more than a useful safety-valve, through which disaffected intellectuals could let off some steam without unduly disturbing or provoking the wider public. I would disagree with such an opinion. Although the writers of these texts were not literary heavyweights in the same division as Pramoedya, and they were not intending to incite millions of villagers to overthrow the President, they were also doing much more than blowing off steam. Their intended audience, the political class of Indonesia, consisted of students, middle-class intellectuals, activists, and, in the case of at least Soebadio and Pipit, Suharto himself. It seems then that their importance lies not so much in their status as literary creators or artists in the serious sense of the word, but as entertainers and social commentators, giving voice to the social and political frustrations of the Indonesian middle class.

As I have tried to show, by reinterpreting the Ramayana, literary "shadow-boxers" such as Pipit, Sindhunata, Soebadio Sastrosatomo, Whani Darmawan and Martin Suhartono took possession of the discourse of the late New Order state, a discourse epitomized by the state-sponsored Rama Tambak phenomenon and its emphasis on the feudal kawula-gusti ethos. In their reworkings of the Ramayana, these writers promoted the social and political aspirations of Indonesia's middle class, mocked the New Order's ruling elite, and satirized and humiliated Suharto. In so doing, they appropriated the Ramayana for their own social and satirical purposes, manipulating it as a means to parody, criticize, and rhetorically undermine the Indonesian authorities, ultimately foreshadowing the overthrow of Suharto and the demise of his New Order regime.

${ }^{120} \mathrm{I}$ am indebted to Budi Sardjono, a Basis editor, for this information.

121 Maier, "Flying a Kite," p. 242. 
